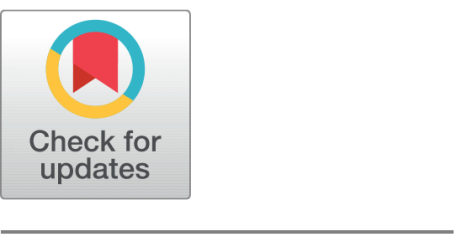

OPEn ACCESS

Received: 25.07.2020

Accepted: 05.09.2020

Published: 20.11 .2020

Editor: Dr. Natarajan Gajendran

Citation: Rajput NH, Bukhari SMA, Noonari N, Rajput JA (2020)

Technology in action: Ascertaining the impact of cell phone calls on middle school students placed at risk of drop out. Indian Journal of Science and Technology 13(40): 4224-4233. https://doi.org/ 10.17485/IJST/v13i40.1236

* Corresponding author.

Tel: 0092-345-2524068 naseem.hyder41@gmail.com

Funding: None

Competing Interests: None

Copyright: (c) 2020 Rajput et al. This is an open access article distributed under the terms of the Creative Commons Attribution License, which permits unrestricted use, distribution, and reproduction in any medium, provided the original author and source are credited.

Published By Indian Society for Education and Environment (iSee)

ISSN

Print: 0974-6846

Electronic: 0974-5645

\section{Technology in action: Ascertaining the impact of cell phone calls on middle school students placed at risk of drop out}

\author{
Naseem Hyder Rajput ${ }^{1 *}$, Syed Muhammad Ahsan Bukhari ${ }^{1}$, \\ Narmeen Noonari ${ }^{1}$, Jabbar Abbas Rajput ${ }^{2}$
}

1 M.Phil. Associate, Department of Education Shaheed Benazir Bhutto University, Shaheed Benazirabad, Pakistan. Tel.: 0092-345-2524068

2 Assistant Professor, Institute of Pharmaceutical Sciences, Peoples University of Medical and Health Sciences for Women, Nawab Shah (SBA)

\section{Abstract}

Background/Objectives: Regular attendance at school is essential for allround development of students. The fundamental objective of this study was to utilize low-cost technology of cell phones to report to parents/guardians about the attendance of their children at schools and ascertain the impacts of cell phone calls on the attendance of Middle School students placed at risk of Drop out. Methods/Statistical analysis: This study was Experimental with a PretestPosttest Control Group by design and descriptive by purpose. The participants were 30 eight graders belonging to a Public Middle School of District Shaheed Benazirabad in Pakistan. These participants were then randomly assigned to Control and Experimental Groups (15 each). For intervention of making cell phone calls to parents/guardians to inform and ask them about the reason for the absence of their child, a teacher in each participating school was assigned this responsibility. The intervention lasted for 3 months. The data was analyzed using SPSS repeated measure t-test to calculate the significance of the impact of intervention. Findings: Results of the present study indicated that the attendance of Experimental Group on Posttest (75.07\%) was significantly higher than that on Pretest (62.87\%). Novelty : This study utilizes existing technology available to almost everyone and bridges the parents and school administration to get the best outcome quickly; mobile-based intervention is simple and docile to regulate students' performance at school level; it also improves the safety of the students.

Keywords: Cell phone calls; impact; students; drop out; middle school

\section{Introduction}

Formal learning generally occurs in a school-based environment and attending schools regularly is both necessary and important for elementary level students to become well-educated, useful, and successful members of society. Such citizens shall not only contribute to the development of society but also play an active role in molding 
a dormant society into a dynamic society. This active role of citizens calls for the possession of skills, actions, attitudes, and knowledge. Attending schools regularly play a very essential part in gaining this knowledge \& in the nurturing and practicing of these skills. Active citizens get involved in healthy activities of the society. Regular attendance of students affects many factors including student him/herself, learning environment of class as well as the whole environment of school. Further, regularly absent students are less likely to transit to their next level of education and even those who continue to be at school irregular remain low at skills needed to become a useful and successful citizen. According to Myers ${ }^{(1)}$, there is a greater likelihood of scoring higher on achievement tests for those students who have better attendance rates. And better attendance scores of students at a school level are positively correlated with higher passing rates in terms of achievement tests ${ }^{(2)}$. Both studies highlight the importance of student attendance in terms of achievement.

Schools and other educational institutions in Sindh are continuously experiencing students' absences from classes on regular basis and this is not only affecting the quality of instruction being given to the students but also the efficiency of the teachers. Despite the immense importance of education and regular attendance at schools 22.84 million students are out of school in Pakistan which means 44 percent of the total child population (aging from 5 years to 16 years) is still not in schools. Sindh also does not have the majority of its child population, or 52 percent, in school, which means over 0.64 million of its children are not in schools. Slight decline was also noted in Pakistan's effective transition rate from elementary to secondary level ${ }^{(3)}$. Overall student attendance in Public schools of Sindh stands at $65 \%$ with 35 percent of the students absent from schools on the day of the visit. The attendance in Middle Schools was still $5 \%$ lower than the overall attendance of Sindh i.e. $60 \%{ }^{(4)}$.

Cell phones can prove to be a powerful competitor in improving students' attendance in the future of education. Cell phones now provide us a route to access those which were previously very difficult to access. It means cell phones are now converting inaccessible to accessible. Cell phone technology can be a major factor in the world of paucity of resources for education. This technology can be used to turn the students' parents more vigilant by supplying them with the information they require to monitor the presence and progress of their children at school. This cell phone technology can be used to engage those who are not currently an active part of the process of education and are particularly remote in terms of distance and contact.

There are 157 million mobile users in Pakistan with 75 percent teledensity. It means that every three persons out of four have subscriptions to cellular services. The subscription of $3 \mathrm{G} / 4 \mathrm{G}$ internet services stands at 65 million with a penetration of 30.86 percent $^{(5)}$. In Pakistan, even zero income earners possess cell phones. According to ${ }^{(6)}$, about one-fourth of zero income earners possess cell phones out of which $85 \%$ have less than primary or no education. According to the same report, cell phone ownership is $57 \%$ in Pakistan. The share of households across all rural districts of Pakistan in terms of possession of cell phones is 68 percent, whereas the share of all rural districts of Sindh with respect to possession of cell phones stands at $55 \%{ }^{(4)}$. There is a major shift in the axis of growth of cell phone services from urban to rural areas as according to ${ }^{(7)}, 63.6 \%$ of Pakistan's total population is still residing in rural areas with Sindh having a share of $47.98 \%$ rural population.

The menace of students' absenteeism has roots in many factors like school-related factors, personal factors, developmental factors, family and parental factors, neighborhood and community factors, ethnic minority status ${ }^{(8)}$. Parents/guardians can play a vibrant part in the reduction of student absenteeism and helping students in achieving their maximum learning potential. Speaking with parents/guardians \& connecting them with their child's education can be a precious \& efficient way in the reduction of students' absenteeism. Regular contacts of the school management with parents/guardians keep parents/guardians up to date about the attendance and its importance for the future success of their child.

Previous researches suggest that unauthorized chronic absenteeism is highly correlated with the completion of schooling. Truancy is a known predictor of students leaving school prior to graduation ${ }^{(9)}$; unauthorized truancy is considered as one of the earliest signals of a prospective school dropout decision and truants are 37.4 percent more likely to drop out of school than regular school attendees ${ }^{(10)}$; truancy is a good predictor of dropping out from elementary school ${ }^{(11)}$; there is a high correlation between truancy and dropping out from school ${ }^{(12)}$; truants are 37.4 percent more likely to drop out of school than regular school attendees ${ }^{(10)}$.

The engagement of parents/ guardians has been studied from the perspective of home visits, sending postcards messages to parents/guardians, using nudge letter approach to improve the attendance of students at schools ${ }^{(13)}$. This study is aimed at engaging parents/guardians through cell phone calls to reduce students' absenteeism rates at a Public Middle School. This intervention of calling students' parents/guardians at their cell phones was dominant in decreasing the student absenteeism rates and highlighted the important role the cell phones can play in fighting the menace of students' absenteeism.

The basis of this quantitative descriptive study is a behavioral science theory and previous experimental data that inform constructive results (i.e improved student attendance) with more involvement of parents/guardians in the educational process of their child. This parental/guardian involvement is achieved in this study using cheaper cell phone technology by informing parents/guardians about the absence of their child through cell phone calls. This study anticipates that when parents/guardians become more cognizant, it will lead to much more involved in the educational process and this will ultimately improve the 
attendance of their child. As this quantitative study is aimed at engaging parents/guardians through cell phone calls, so it is aimed at ascertaining the impact of regular cell phone calls on the attendance of elementary level students.

\subsection{Definitions}

- Attendance: Here attendance of a student means "number of days attended by a student in a month". Its percentage is calculated by dividing the no. of days attended by total no. of working days in a month multiplied by 100 .

- Absenteeism: Any day missed at school by a student without intimation to school is considered here as "absenteeism".

- Risk of dropping out: Likelihood of drop out from school due to noncompliance of $75 \%$ compulsory attendance requirement according to rule.

\section{Literature Review}

Attending school regularly is essential for students to acquire not only better health results but also educational outcomes. It facilitates students in achieving important expertise like problem-solving, social skills and work collaboratively ${ }^{(14)}$. In contrast, students who are not attending schools on regular basis are more prone to score lower on standardized tests, lesser skills in mathematics \& reading with a greater probability of dropping out in afterward classes ${ }^{(15)}$. Absenteeism must be tackled from the perspectives of students' surrounding community as it is a general apprehension. Agencies, organizations, businesses, and local citizens can work collaboratively with schools and assist them in decreasing absences ${ }^{(16)}$. Schools must understand the requirements of the absent students in order to use these community-based resources including parents efficiently in the reduction of students' absences as different students may have different problems that may hinder their regular attendance at school. For example, a student from a low-income background may lack support in terms of clothing and nutrition and both these factors may add positively to regular school attendance.

Parents and legal guardians of the students can be connected to their child's educational process through regular communication with them. This regular communication can be very precious and efficient in the reduction of students' absenteeism. These regular communications with families of the students make them understand the important role that regular attendance at school can play in the all-round success of the student ${ }^{(17)}$. A combination of home visits, regular communications with parents/guardians and their involvement can successfully reduce chronic absenteeism ${ }^{(18)}$. This two-way communication makes strong links between school, community, and parents ${ }^{(19)}$. Two-way communication is important for school partnerships to be successful ${ }^{(20)}$. With respect to contact between schools \& families, for increasing trust the better school-home communication is the most efficient procedure ${ }^{(21)}$. According to ${ }^{(22)}$, the only formula to contact parents is that each school should choose on the actions \& structures that are appropriate according to the mission of the school \& local circumstances. Therefore, schools are required to prepare efficient design and structure of two-way communication between school and home. These designs and structures should aim at informing parents about programs at schools and the progress of their children. This will result in enhanced awareness of parents about the educational process and will consequently improve the attendance of their child.

In this regard, conventional procedures of communication like face to face meetings are proven effective ${ }^{(23)}$; but these procedures have serious drawbacks in terms of time required for such procedures and obviously, both parents and teachers are short of time. To overcome this time constraint and acquire the objective of better communication between homes and school certain technological platforms can be used. In this regard, cheaper cell phone technology can be applied to make calls regularly to the parents of absent students. This will also avoid the problems and hazards of physical traveling and visits either of parents to school or of teachers to students' homes. Nowadays due to technology capable ways are available to disseminate information to parents ${ }^{(23)}$.

Newsletters, emails, translated materials, postings through web, telephone calls, home visits, videos or photo albums are some of the ways that teachers and administrators select from to communicate with the parents ${ }^{(24)}$. Electronic mail still enjoys the status of most favored procedure of making contact between school \& parents ${ }^{(25)}$. Electronic mail is effective over cost, more effective than notes in terms of reachability, could be less formal than letters, enhances community responsiveness, nourishes public relations positively, \& helps in identifying and converting parents into technology advocates ${ }^{(26)}$. All these elements help and improve communication between schools and parents. But this method of communication has certain serious limitations and drawbacks. Firstly, not all parents have access to the internet which is necessary for sending and receiving messages through electronic mail. In some rural areas where luckily the internet is available, the speed of the internet is too slow to communicate through email. In some cases, it takes even hours to just open the inbox of email because of too slow internet speed. Further there only a few who are in possession of computers and the latest gadgets required for communicating through email. This problem becomes graver especially in the rural context of Sindh with low literacy rates and no availability of such technological 
platforms. So, those parents who do not have theses technological facilities available will be unable to benefit from these and will be disadvantaged. The second problem arises with the misinterpretation of mailing texts which are mostly short in length with not clearly highlighting the underlying concern and such misinterpretations have great effects on the communication between school and parents.

Another method is text messaging which is more attractive for teacher-parents communication as it offers the ease of use because it is available anywhere and anytime. With this method as the sender has the liberty of sending messages anytime in the same way the intended receiver may manage when to read \& respond to the messages ${ }^{(27)}$. Text messages also have the advantage over jammed and busy phone lines as they ensure instant delivery of the message with less chances of delivery failure. This results in instant communication between schools and parents. This method also has certain limitations. Although the number of cell phone users is significant unlike the internet and computer users in rural areas, yet they are not equal to those who can also read those messages because of low literacy rates. Another limitation with this form of communication is that it is not necessary that the person whom you are sending the message is also reading the message because even some literate persons are in habit of using cell phones only for voice calls. Whatever might be the importance of text message they just delete the message even without looking at the sender of the message.

\section{Materials and Methods}

\subsection{Research design}

This study was Experimental with a Pretest-Posttest Control Group by design and descriptive by purpose.

\subsection{Participants}

There was a total of 30 eight graders belonging to a Public Boys High School of District Shaheed Benazirabad, Pakistan who were identified as being placed at risk of dropping out from school because of low attendance in school. These participants were selected based on a bi-dimensional criterion; identification by teachers of those students who were experiencing substantial problems in attending school and an attendance of $60 \%$ or lower on school record.

\subsection{Setting and demographic information}

The study was conducted in a Public Boys High School of District Shaheed Benazirabad. The majority of the participating students were residing within a radius of approximately two to three kilometers to the schools and had to walk on foot in the scorching beams of sunlight in summer days. Out of a total of 30 participants, 15 students belonged to Sindhi-speaking families, 10 belonged Urdu and 5 belonged to Saraiki-speaking families. There were two mediums of instruction; Sindhi and Urdu. 20 students were of Sindhi medium and 10 of Urdu medium. The mean age of the students was 12.75 years. Details are given in Table 1.

Table 1. Setting and demographic information

\begin{tabular}{|c|c|c|c|c|c|c|c|c|c|c|}
\hline $\begin{array}{l}\text { Serial } \\
\text { No. }\end{array}$ & School & $\begin{array}{l}\text { No. of Partici- } \\
\text { pants }\end{array}$ & Gender & $\begin{array}{l}\text { Average } \\
\text { (Years) }\end{array}$ & Age & \multicolumn{2}{|c|}{ Ethnicity } & \multicolumn{2}{|c|}{ Medium of Instruction } & $\begin{array}{l}\text { No. of School } \\
\text { Teachers }\end{array}$ \\
\hline \multirow{4}{*}{1} & \multirow{4}{*}{1} & \multirow{4}{*}{30} & \multirow{4}{*}{ All Boys } & \multirow{4}{*}{12.75} & & Sindhi & 15 & Sindhi Medium & 20 & \multirow{4}{*}{14} \\
\hline & & & & & & Urdu & 10 & \multirow{2}{*}{ Urdu Medium } & \multirow{2}{*}{10} & \\
\hline & & & & & & Saraiki & 05 & & & \\
\hline & & & & & & Total & 30 & Total & 30 & \\
\hline
\end{tabular}

\subsection{Instrumentation}

The quantitative data about students' monthly mean baseline attendance and the impact of regular cell phone calls on the attendance of eighth-graders were collected through school attendance records maintained by the schools daily.

\subsection{Procedure}

Technology in the form of cell phones to make calls to inform the parents about their children's absence was used to achieve the primary objective of ascertaining its impacts on middle school level students' attendance. To implement the study, one Public 
Boys High School was randomly selected to participate in the study. Then Head Teacher of participating school was contacted to obtain his permission for the study to be contacted in his school. Permission was also sought from the parents/guardians of 30 participating students belonging to this school. The contact numbers of parents/guardians were obtained through the class teacher. All parents owned operational cell phones with valid contact numbers and were requested to always keep switched on their cell phones to receive calls from calling teachers of their children. The calling teachers were also in possession of operational cell phones with valid contact numbers. Finally, thirty participants were randomly assigned to the Experimental Group and Control Group (fifteen in each group). For controlling the calling teachers' effects, teachers were also randomly assigned to treatment and Experimental Groups.

\subsection{Intervention}

\subsubsection{Experimental group}

The monthly mean baseline (Pretest) attendance of participants of the Experimental Group was obtained from the daily attendance register maintained by the school. Mean baseline attendance (Pretest) was recorded based on 3 months mean attendance immediately before the intervention month. Then parents of fifteen participants of the Experimental Group received cell phone calls from the randomly assigned teacher of the school. The process was that whenever a student missed a day in school without intimation to school, the teacher contacted his parents/guardians and informed them about the absence of their child and asked to give feedback about the reason/s of absence. The teacher also emphasized and explained the importance of regular attendance to the parents. This intervention of making on cell phone calls lasted for three months (January, February, and March) excluding Sundays and public holidays. The Experimental Group was post-tested by noting the final attendance at the end of the intervention. The score of posttest were compared with the posttest score of Control Group to determine the effectiveness of the intervention.

\subsubsection{Control group}

The Control Group was pretested by taking mean baseline attendance from the school attendance register. The Control Group received traditional treatment according to the local circumstances for informing the parents of participants. These included informing parents/guardians through warning notices and personal messages carried by the teachers and students living nearby of absent students; verbal warnings carried by the lower staff of the school to the parents and making announcements in the mosques of the villages where students were missing out of schools. Whenever a participant in the Control Group missed out a day in school, the teacher informed his parents in the form of one of the above-mentioned strategies. The Control Group was post-tested by noting the final attendance at the end. The score of posttest was compared with the posttest score of Experimental Group to determine the effectiveness of the intervention.

\subsection{Data analysis}

Data was analyzed using SPSS and repeated measure t-test (A 2 group x 2-time testing: pre and post) was used to determine the equivalency of pretreatment groups, significance of the differences found in the pretest and posttest scores and following results were obtained after the data analysis.

\section{Findings}

Table 2. Control group pretest data

\begin{tabular}{llllll}
\hline & $\mathrm{N}$ & Minimum & Maximum & Mean & Std. Deviation \\
\hline Attendance (\%) Valid N (Listwise) & 1515 & 60.00 & 66.00 & 63.00 & 1.93 \\
\hline
\end{tabular}

According to data presented in Table 2, the average pretest attendance of Control Group is $63 \%$ with 1.93 SD.

Table 3. Experimental group pretest data

\begin{tabular}{llllll}
\hline & $\mathrm{N}$ & Minimum & Maximum & Mean & Std. Deviation \\
\hline Attendance (\%) Valid N (Listwise) & 15 & 60.00 & 66.00 & 62.87 & 1.96 \\
\hline
\end{tabular}

According to data presented in Table 3, the average pretest attendance of Experimental Group is $62.87 \%$ with 1.96 SD. 
Table 4. Comparative pretest data of control and experimental groups

\begin{tabular}{llllll}
\hline & Group & N & Mean & Std. Deviation & Std. Error Mean \\
\hline Attendance (\%) & Ctrl Grp Exp Grp & 1515 & 63.0062 .87 & 1.931 .96 & 50.51 \\
\hline
\end{tabular}

According to data presented in Table 4, the average pretest attendance of the Experimental Group is 62.87 with 1.96 SD. It reveals that the pretest attendance Experimental Group is slightly lower than the pretest attendance of Control Group (63). The pretest attendance of Experimental Group is also slightly more spread out (1.96) around the mean as compared to the pretest attendance of Control Group (1.93)

Table 5. Pre intervention group equivalency

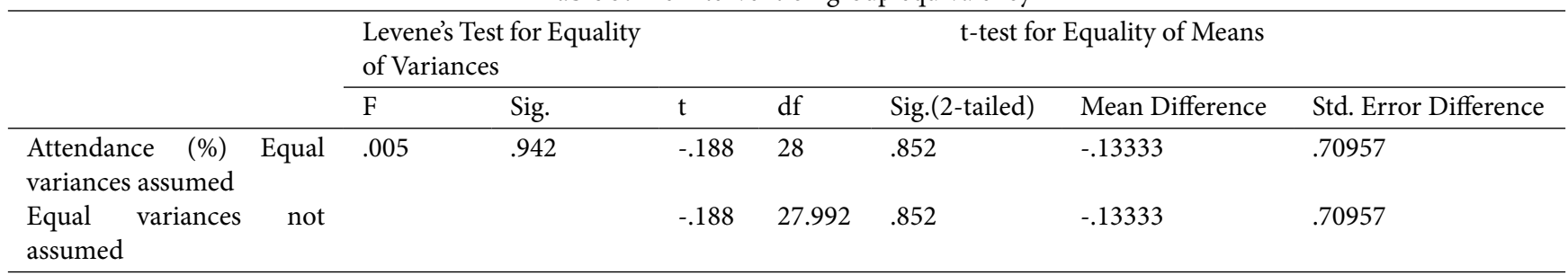

Both the experimental and Control Groups were pretested to determine their equivalency on the measured variable through a two-tailed student t-test and Levene's test for equality of variances. Results presented in Table 5, indicate that both the groups are not significantly different on the pretest mean attendance (Experimental Group $=62.87$, Control Group $=63)$, $t(28)=.188$, $\mathrm{p}<.852$.

\subsection{Impact of cell phone calls on students' attendance}

Paired sample t-test was performed to gauge the impact of cell phone calls on students' attendance.

Table 6. Control group posttest data

\begin{tabular}{llllll}
\hline & $\mathrm{N}$ & Minimum & Maximum & Mean & Std. Deviation \\
\hline Attendance (\%) Valid N (Listwise) & 1515 & 62.00 & 68.00 & 65.07 & 2.02 \\
\hline
\end{tabular}

According to data presented in Table 6, the average posttest attendance of Control Group was $65.07 \%$ with 2.02 SD.

Table 7. Experimental group posttest data

\begin{tabular}{llllll}
\hline & $\mathrm{N}$ & Minimum & Maximum & Mean & Std. Deviation \\
\hline Attendance (\%) Valid N (Listwise) & 1515 & 75.00 & 79.00 & 77.13 & 1.13 \\
\hline
\end{tabular}

According to data presented in Table 7, the average posttest attendance of Experimental Group was $77.13 \%$ with 1.13 SD.

Table 8. Comparative posttest data of control and experimental groups

\begin{tabular}{llllll}
\hline & Group & N & Mean & Std. Deviation & Std. Error Mean \\
\hline Attendance (\%) & Ctrl Grp Exp Grp & 1515 & 65.0777 .13 & 2.021 .13 & .52 .29 \\
\hline
\end{tabular}

According to data presented in Table 8, the average posttest attendance of the Experimental Group was 77.13 with 1.13 SD. It reveals that the post attendance of the Experimental Group is very much higher than the posttest attendance of Control Group (65.07). The posttest attendance of Control Group (2.02) is slightly more spread out around the mean as compared to the pretest attendance of Experimental Group (1.13). 
Table 9. Comparative pretest-posttest data of control and experimental groups

\begin{tabular}{llll}
\hline Comparison of Control Group & & Comparison of Experimental Group \\
\hline Pretest Mean & Posttest Mean & Pretest Mean & Posttest Mean \\
\hline 63.00 & 65.07 & 62.87 & 77.13 \\
Difference $=2.07$ & & Difference $=14.27$ & \\
Net Impact: $14.27-2.07=12.20$ & & & \\
\hline
\end{tabular}

According to data presented in Table 9, the pretest-posttest difference of Control Group was 2.07. The pretest and posttest difference of the Experimental Group was 14.27. When Control Group pretest-posttest difference was subtracted from Experimental Group pretest-posttest difference we reached a net impact of 12.20 in Experimental Group mean baseline attendance.

Table 10. Comparative statistics of pretest and posttest

\begin{tabular}{lllll}
\hline & Mean & N & Std. Deviation & Std. Error Mean \\
\hline Pretest Posttest & 62.8775 .07 & 1515 & 1.202 .80 & .51 .72 \\
\hline
\end{tabular}

According to data presented in Table 10, pretest mean was 62.87 with 1.2 SD. The posttest mean attendance stood at 75.07 with $2.80 \mathrm{SD}$ which shows that posttest mean is more spread out as compared to the pretest mean.

Table 11. Paired Sample t-test output

\begin{tabular}{lllllll}
\hline & $\begin{array}{l}\text { Paired } \\
\text { ences }\end{array}$ & Differ- & \multirow{2}{*}{ d } & df & Sig. (2-tailed) \\
\cline { 2 - 5 } & Mean & Std. Deviation & Std. Error Mean & & \\
\hline Pair 1 Pretest-Posttest & -12.20 & 3.02844 & .78194 & -15.602 & 14 & .000 \\
\hline
\end{tabular}

According to the results presented in Table 11 , there was a significant difference between the pretest and posttest mean attendance of Experimental Group where posttest attendance outperformed pretest attendance. Results indicate that Experimental Group significantly improved its performance from pretest to post test (mean difference $=-12.20$, Standard Deviation $=3.02844, \mathrm{t}(14)=-15.602, \mathrm{p}<.000)$.

\section{Discussion}

This study investigated the impact of cell phone calls on the attendance of eight graders placed at risk of dropping out from school due to noncompliance of seventy-five percent compulsory attendance requirements. Results indicated that the post test performance of the Experimental Group was significantly better than pretest performance of Experimental Group on students' attendance. These results support and extend previous studies about the effectiveness of technology in reducing absenteeism at schools e.g., ${ }^{(18,28,29)}$. Further, this intervention was different from that of ${ }^{(28)}$ as it targeted at-risk students of different education level (Middle School) and used technology differently (for calling).

In general, results indicated a significant mean difference (12.20\%) between pretest and post test attendance of students of the Experimental Group. This impact is slightly larger than reported in the study of ${ }^{(28)}$. In that study, by the end of the intervention year, $13.3 \%$ of Bridges kindergarteners were chronically absent, compared to a rate of $24.4 \%$ for the synthetic comparison, a difference of 11.1 percentage points. It might be due to certain limitations that are always associated with text messaging. Although the number of cell phone users is significant unlike the internet and computer users, yet they are not equal to those who can also read those messages because of varying literacy rates. Another limitation with this form of communication is that the person whom you are sending the message doesn't need to be also reading the message because even some literate persons are in habit of using cell phones only for voice calls. Whatever might be the importance of text message they just delete the message even without looking at the sender of the message.

Although the results of the present study confirm previous researches on mobile phone usage by ${ }^{(18,28,29)}$, an elaboration of more positive impact in our study when compared to prior research on other technological uses for reducing absenteeism e.g., ${ }^{(30,31)}$ is necessary. In the studies ${ }^{(30)} \&^{(31)}$, for example, it was established that informing parents about the number of days missed at school by their children using email led to ten percent and 2.5 per cent improvement of attendance of their children at school.

Emailing can help and improve the communication between schools and parents. But this method of communication has certain serious limitations and drawbacks when applied to developing parts of the Globe. Firstly, not all parents have access 
to the internet which is necessary for sending and receiving messages through electronic mail. In some rural areas where luckily the internet is available, the speed of the internet is too slow to communicate through email. In some cases, it takes even hours to just open the inbox of email because of too slow internet speed. Further there only a few who have computers and the latest gadgets required for communicating through email. This problem becomes graver especially in the rural context of Sindh with low literacy rates and no availability of such technological platforms. So, those parents who do not have theses technological facilities available will be unable to benefit from these and will be disadvantaged. The second problem arises with the misinterpretation of mailing texts which are mostly short in length with not highlighting the underlying concern and such misinterpretations have great effects on the communication between school and parents.

However, the findings of this study do not support some of the previous researches that used low-cost mobile technology. In a civic engagement program is Punjab that was utilized to regularly engage with autonomous school council members through scheduled calls via a call center, the cell phone calls did not increase the students' attendance ${ }^{(32)}$. In order to understand this contradiction, it is important to understand the context and nature of this intervention. Current intervention engaged parents/guardians of the students that were more linked to the students when compared to the school council members. In current study the parents/guardians were contacted by school teachers via unscheduled calls not by a call center representative through scheduled calls. This also found support in literature that demonstrates that supporting sole civic participation is not effective. In India, a program in which training and information were provided to the Village Education Committees with the help of NGOs did not prove effective ${ }^{(33)}$.

\section{Limitations}

There are certain limitations to this study which require cautious interpretation of the findings. First, the sample size was minimum because there were only 30 eight graders which were placed at risk of drop out. The researcher could not artificially increase the sample size. Second, the sample only included the Boys students because there are separate schools for Boys and Girls in Pakistan

\section{Implications for practice}

Participants demonstrated an increase in their monthly mean baseline attendance so, this cheap intervention can be beneficial in addressing the problem of students' absences especially in the rural areas of Sindh where students come to school from far off places and physically it is very difficult for the teachers to travel to the homes of those students to inform their parents. Approximately everyone possesses a cell phone even in rural areas. This form of sharing information with the parents about the absence of their children at schools is different in the sense that it provides asynchronous communication through which the essence and gravity of the problem can be directly conveyed to the parents and their views can be simultaneously obtained about the concerning problem. This cheap intervention can be applied in Middle Schools of rural Sindh to increase not only the attendance of the students at school but also to appraise their parents on a timely basis. Timely Parental involvement in the educational process of their child will not only improve the attendance of the students at schools but also prove to help increase the awareness of the parents about the importance of regular school attendance which will ultimately improve the achievement of students. Monthly mean increases of $12.20 \%$ in the baseline attendance of $62.87 \%$ means a student can attend 3.7 days more in a 26 working days of the month which means 18 hours more study in the school. And obviously, every moment is crucial in the life of students, especially at the early stages, as these pave the way and laid the foundation for tomorrow. On the other hand, a breakdown in the communication between the school and parents can result in unawareness of the parents about the status of their children's attendance at schools as parents in rural areas don't bother to even go to the school in months. This breakdown in communication is neither required by the parents nor by the school as permanent lines of communication is very essential for the all-round achievement and development of the students. Readily available fresh, authentic and firsthand information about the reason behind the absence of the student from school can help class teachers in immediately devising strategies and plans to decide what motivation can be provided to the absent students according to their underlying problems to transform them from dormant to more proactive learners. In situations where such breakdowns in communication exist these can block effective dissemination of information from school to parents and vice versa. This source of communication will not only disseminate information about regular attendance but also all the other necessary facts and hard questions can be timely transferred to the parents. However, the nature of this intervention does not exclude the possibility of other steps to be taken for the enhancement of students' attendance at schools. But when combined with other steps for the improvement of student attendance in collaboration with local community and stakeholders, the efficiency of this intervention can be further increased. 


\section{Conclusion}

Previous studies indicate that regular students' attendance at school is a major problem the Public Schools of Sindh are facing. Because of this major problem, students suffer and lack behind in the achievement of their lifelong goals. The fundamental objective of this study was to ascertain the impact of regular cell phone calls on attendance of elementary level students. This study indicates a positive impact (12.20\% increases) of cell phone calls on students' attendance of students placed at risk of Drop out from school. Eight graders have a special requirement to address the issue of regular school attendance as they are on the verge of shifting to another level of their education. This can prove to be a positive factor in improving the students' attendance. It is now a fact that the success of students can be increased by involving their parents in their educational process and this can be achieved effectively using this cheap, readily available technology in the form of cell phones.

\section{Recommendation}

It is recommended that School administrations should employ this readily available technology as a tool to reduce the absenteeism of the students at their schools.

\section{References}

1) Nanney M, Myers S, Xu M, Kent K, Durfee T, Allen M. The Economic Benefits of Reducing Racial Disparities in Health: The Case of Minnesota. International Journal of Environmental Research and Public Health. 2019;16. Available from: https://dx.doi.org/10.3390/ijerph16050742.

2) Ehrenberg RG, Ehrenberg RA, Rees DI, Ehrenberg EL. School district leave policies, teacher absenteeism, and student achievement. National Bureau of Economic Research. 1989. Available from: https://doi.org/10.3386/w2874.

3) Pakistan Education Statistics 2016-17. . Available from: http://library.aepam.edu.pk/Books/Pakistan\%20Education\%20Statistics\%202016-17.pdf.

4) Idara-E-Talee-O-Agahi. Annual Status of Education Report (ASER). 2019. Available from: http://aserpakistan.org/document/aser/2019/reports/national/ ASER_National_2019.pdf.

5) Pakistan Telecommunication Authority (PTA). Pakistan Telecommunication Authority Annual Report 2018. 2018. Available from: https://www.pta.gov. $\mathrm{pk} / \mathrm{en} / \mathrm{annual}-$ reports.

6) Rizvi J. Pakistan's urban-rural mobile ownership divide set to close soon. 2018. Available from: https://www.thenews.com.pk/print/391338-pakistan-surban-rural-mobile-ownership-divide-set-to-close-soon-study-shows.

7) Pakistan Bureau of Statistics. 6th Population \& Housing Census 2017. 2020. Available from: http://www.pbs.gov.pk/content/population-census.

8) Teasley ML. Absenteeism and Truancy: Risk, Protection, and Best Practice Implications for School Social Workers. Children \& Schools. 2004;26(2):117128. Available from: https://dx.doi.org/10.1093/cs/26.2.117.

9) Garry EM. Truancy, first step to a lifetime of problems. US Department of Justice, Office of Justice Programs, Office of Juvenile Justice and Delinquency Prevention. 1996. Available from: https://doi.org/10.1037/e306412003-001.

10) Cabus SJ, Witte KD. Does unauthorized school absenteeism accelerates the dropout decision? - Evidence from a Bayesian duration model. Applied Economics Letters. 2015;22(4):266-271. Available from: https://dx.doi.org/10.1080/13504851.2014.937031.

11) Lehr CA, Sinclair MF, Christenson SL. Addressing Student Engagement and Truancy Prevention During the Elementary School Years: A Replication Study of the Check \& Connect Model. Journal of Education for Students Placed at Risk (JESPAR). 2004;9:279-301. Available from: https://dx.doi.org/10. 1207/s15327671espr0903_4.

12) Miller F. School-Based Truancy Courts. In: and others, editor. Encyclopedia of Social Work. 2019. Available from: https://doi.org/10.1093/acrefore/ 9780199975839.013.1065.

13) Lara J, Noble K, Pelika S, Coons A. Chronic Absenteeism. NEA Research Brief. NBI No. 57. National Education Association. 2018.

14) Kearney CA, Graczyk P. A Response to Intervention Model to Promote School Attendance and Decrease School Absenteeism. Child \& Youth Care Forum. 2014;43(1):1-25. Available from: https://dx.doi.org/10.1007/s10566-013-9222-1.

15) Balfanz R, Byrnes V. Chronic absenteeism: Summarizing what we know from nationally available data. Baltimore: Johns Hopkins University Center for Social Organization of Schools. Baltimore. Johns Hopkins University Center for Social Organization of Schools. 2012.

16) Epstein JL. School, family, and community partnerships. In: and others, editor. Preparing educators and improving schools. Routledge. 2018. Available from: https://doi.org/10.4324/9780429493133.

17) Sheldon SB, Jung SB, Johns Hopkins University. Student outcomes and parent teacher home visits. 2018. Available from: http://www.pthvp.Org/wpcontent/uploads/2018/12/181130-StudentOutcomesandPTHVReportFINAL.Pdf.

18) Robinson CD, Lee MG, Dearing E, Rogers T. Reducing Student Absenteeism in the Early Grades by Targeting Parental Beliefs. American Educational Research Journal. 2018;55(6):1163-1192. Available from: https://dx.doi.org/10.3102/0002831218772274.

19) O'Toole L, Kiely J, Mcgillicuddy D. arental Involvement, Engagement and Partnership in their Children's Education during the Primary School Years. National Parents Council. 2019.

20) Leenders H, de Jong J, Monfrance M, Haelermans C. Building strong parent-teacher relationships in primary education: the challenge of two-way communication. Cambridge Journal of Education. 2019;49(4):519-533. Available from: https://dx.doi.org/10.1080/0305764x.2019.1566442.

21) Bordalba MM, Bochaca JG. Digital media for family-school communication? Parents' and teachers' beliefs. Computers \& Education. 2019;132:44-62. Available from: https://dx.doi.org/10.1016/j.compedu.2019.01.006.

22) Murray B, Domina T, Renzulli L, Boylan R. Civil Society Goes to School: Parent-Teacher Associations and the Equality of Educational Opportunity. RSF: The Russell Sage Foundation Journal of the Social Sciences. 2019;5(3):41-63. Available from: https://dx.doi.org/10.7758/rsf.2019.5.3.03.

23) Berklan S, Hughes T. Is Innovation Outpacing Insight: Why Schools Need Policy to Address Communication Practices with Parents. eJournal of Education Policy. 2020;21. Available from: https://dx.doi.org/10.37803/ejeps2010.

24) Haney SN. Communication Technology and Parent-Caregiver Relationship Quality in Early Childhood . . 
25) Schwartz D, Kelleghan A, Malamut S, Mali L, Ryjova Y, Hopmeyer A, et al. Distinct Modalities of Electronic Communication and School Adjustment. Journal of Youth and Adolescence. 2019;48:1452-1468. Available from: https://dx.doi.org/10.1007/s10964-019-01061-8.

26) Wong-Villacres M, Ehsan U, Solomon A, Buil P, Disalvo M, B. Design guidelines for parent-school technologies to support the ecology of parental engagement. In: and others, editor. Proceedings of the 2017 Conference on Interaction Design and Children. 2017;p. 73-83. Available from: https: //doi.org/10.1145/3078072.3079748.

27) Juma MA. An automated interface design for student-parent interaction in secondary boarding schools: a study of schools in rachuonyo south sub-county, Kenya ..

28) Smythe-Leistico K, Page LC. Connect-Text: Leveraging Text-Message Communication to Mitigate Chronic Absenteeism and Improve Parental Engagement in the Earliest Years of Schooling. Journal of Education for Students Placed at Risk (JESPAR). 2018;23(1-2):139-152. Available from: https://dx.doi.org/10.1080/10824669.2018.1434658.

29) Lawpoolsri S, Khamsiriwatchara A, Liulark W, Taweeseneepitch K, Sangvichean A, Thongprarong W, et al. Real-Time Monitoring of School Absenteeism to Enhance Disease Surveillance: A Pilot Study of a Mobile Electronic Reporting System. JMIR mHealth and uHealth. 2014;2(2). Available from: https://dx.doi.org/10.2196/mhealth.3114.

30) Rogers T, Feller A. Reducing student absences at scale. Unpublished paper. 2016.

31) Rogers T, Duncan T, Wolford T, Ternovski J, Subramanyam S, Reitano A. A Randomized Experiment Using Absenteeism Information to" Nudge" Attendance. REL 2017-252. Regional Educational Laboratory Mid-Atlantic. 2017.

32) Asim M, Dee T. Mobile phones, civic engagement, and school performance in Pakistan. 2016.

33) Banerjee AV, Banerji R, Duflo E, Glennerster R, Khemani S. Pitfalls of Participatory Programs: Evidence from a Randomized Evaluation in Education in India. American Economic Journal: Economic Policy. 2010;2(1):1-30. Available from: https://dx.doi.org/10.1257/pol.2.1.1. 